\title{
PENEGAKAN HUKUM LINGKUNGAN ADMINISTRATIF DALAM UNDANG-UNDANG PERLINDUNGAN DAN PENGELOLAAN LINGKUNGAN HIDUP
}

\author{
Oleh: \\ $\mathrm{K}$ a r to no \\ Fakultas Hukum Universitas Jenderal Soedirman Purwokerto
}

\begin{abstract}
General population growth has increased with increasing environmental risk and high consumption of chemical-based products. This condition requires the need for environmental laws tougher life than before. Therefore, on 8 September 2009 and then, the House has passed the bill Protection and Management of the Environment into law. One of the new things in this legislation is the creation of a new type of license, i.e environmental permit. The aim is to strengthen the supervisory authority of the Ministry of Environment protection and environment management. However, the law does not regulate the supervision institutions, so that the authority is structurally integrated into the existing institutions. With such authority, the government should reform the laws and regulations which can substantially support the performance monitoring, both regarding the amount of oversight, supervision and frequency standards of supervision. But on the other aspects of supervision as a form of preventive law enforcement is also facing challenges related inconsitency legal terminology in its formulation. It is necessary for creativity in its application of law enforcement so that law enforcement process does not face constraints in the implementation means.
\end{abstract}

Kata Kunci : pengawasan, izin lingkungan, penegakan hukum

\section{A. Pendahuluan}

Ancaman terhadap kelestarian lingkungan dewasa ini semakin meningkat. Buruknya kualitas lingkungan antara lain ditandai dengan meningkatnya eksploitasi sumberdaya alam yang menghasilkan limbah industri. Kira-kira 250 ribu ton limbah industri telah dibuang selama tahun 1990 dan diperkirakan meningkat menjadi 1,2 juta ton pada tahun 2010, termasuk 1 juta ton zat beracun seperti logam berat, pestisida dan senyawa organik yang sangat toksik dan persisten di dalam lingkungan. ${ }^{1}$ Sementara laju perusakan hutan juga meningkat dari 1,6 juta hektar/tahun pada 1985- 1987, menjadi 2.1 juta hektar/tahun pada 1997-2001. Laporan tahun Kementerian Lingkungan Hidup meberikan data bahwa meskipun hutan tropis Indonesia kini hampir habis, laju deforestasi justru semakin meningkat hingga 3,6 juta hektar pertahun. Saat ini

Lembaga Kajian Ekologi dan Konservasi Lahan Basah, 2005, Melaksanaan Pembangunan Berkelanjutan Dengan Menegakkan Hukum Lingkungan Bagi Pencemar, 5 Juni 2002 sekitar 59,2 juta hektar atau sekitar 50\% dari total kawasan hutan yang ada, 120.35 juta hektar kawasan hutan perlu direhabilitasi. ${ }^{2} \mathrm{Di}$ sinyalir perusakan hutan ini merupakan salah satu sebab utama terjadinya peningkatan duhu bumi. Di samping akibat penggunaan bahan bakar fosil baik dari sumber bergerak maupun tidak bergerak yang terus meningkat jumlahnya. Dalam duapuluh tahun terakhir saja terjadi kenaikan suhu udara 1.7 derajat Celcius dari sebelumnya 33 derajat Celcius menjadi 34,7 derajat Celcius. ${ }^{3}$

Beberapa data terakhir tentang kondisi lingkungan di Indonesia menunjukkan tingginya tingkat pemanfaatan sumberdaya alam yang menimbulkan peningkatan kerusakan serta pencemaran lingkungan, antara lain: ${ }^{4}$

\footnotetext{
Kementerian Lingkungan HIdup, Laporan Menteri Lingkungan Hidup Tahun 2005, Jakarta, hlm. 3 Kompas, Kamis, 24 April 2008 ।

Kementerian Lingkungan Hidup, 2004, Environmental Parliament Watch (EPW) Menuju Perwujudan Peran Masyarakat, Jakarta: Deputi Bidang Pengembangan Peran Masyarakat, hlm. 1-3
} 
a. Pertumbuhan penduduk dari tahun $1980 \mathrm{~s} / \mathrm{d}$ 2000 meningkat dengan cepat. Yaitu, pada tahun 1980 penduduk Indonesia masih berjumlah 146.935.000 jiwa dan bertambah sebanyak $1.97 \%$ menjadi 178.500 .000 jiwa pada tahun 1990. Pada tahun 2000 jumlah penduduk Indonesia menjadi 205.845.000 jiwa atau naik $1.49 \%$ dengan kepadatan mencapai 109 jiwa per $\mathrm{km} 2$. Hal ini telah meningkatkan eksploitasi sumberdaya secara besarbesaran yang mengakibatkan terjadinya kerusakan lingkungan.

b. Hasil penelitian WHO, 2001 menunjukkan bahwa pencemaran udara di kota besar dunia menduduki lima terbesar di dunia yang diakibatkan kegiatan transportasi, industri dan kebakaran hutan. Menurut World Bank 60 - 70\% pencemaran udara diakibatkan gas buang kendaran bermotor.

c. Terumbu karang kondisinya sudah semakin mencemaskan, sekitar $14 \%$ dalam kondisi kritis, $46 \%$ telah mengalami kerusakan, 33\% dalam kondisi masih cukup baik dan hanya $7 \%$ kondisinya masih sangat baik.

d. Hutan mangrove Indonesia diperkirakan tinggal 3,24 juta hektar dari 4,25 juta hektar, sedangkan hasil citra landsat tahun 1992, hutan mangrove Indonesia masih sebesar 3.737.000 hektar.

e. Deposisi asam rata-rata derajat keasaman (pH) beban air hujan selama lima tahun terakhir di berbagai daerah Indonesia berkisar antara $4.8 \mathrm{~s} / \mathrm{d}$ 5.8, kondisi ini menunjukkan bahw air hujan di sebagian besar wilayah Indonesia telah berada di bawah nilai pH normal, yaitu: 5.6 - 7.5. Atau telah mencerminkan sifat air hujan asam.

f. Pengalihan pemanfaatan lahan untuk pembangunan terus berlanjut yang mengakibatkan berkurangnya atau hilangnya lahan-lahan yang berfungsi sebagai penopang keseimbangan lingkungan. Areal air tawar telah berkurang dari 11.5 juta hektar menjadi 5.1 juta hektar, danau berkurang dari 774.000 hektar menjadi 308.000 hektar.

Mega degradasi lingkungan nyaris tak terbendung dan membuat rakyat Indonesia semakin menderita. New York Times edisi 26
Desember 2005 menyebut operasi tambang PT Freeport saja di Papua sejak tahun 1967 telah memproduksi limbah sebanyak 6 miliar ton atau lebih dari dua kali lipat dibandingkan dengan seluruh hasil galian dalam pembangunan terusan Panama. ${ }^{5}$

Untuk pulau Jawa, jika tidak terdapat kebijaksanaan penyebaran industri ke luar Jawa, maka emisi total yang ada saat ini akan meningkat enam kali lipat pada tahun 2010. Apabila tidak terdapat kebijaksanaan nyata untuk mengatasi keadaan ini, pada tahun 2010 sekitar $85 \%$ dari korban infeksi saluran pernapasan (inflmammation of the respiratory fract) akan terdapat di pulau Jawa, dan hanya 15\% di luar Jawa, khususnya di Sumatera Utara, Kalimantan Selatan, dan Bali. ${ }^{6}$

Dinamika masalah lingkungan berkembang lebih cepat dari yang diperkirakan sebelumnya yang dipicu terutama oleh pertumbuhan penduduk. Pertumbuhan penduduk ini telah meningkatkan konsumsi dan pemakaian produk berbasis bahan kimia yang meningkatkan produksi limbah bahan berbahaya dan beracun serta masalah-masalah lingkungan lainnya. Perkembangan itu mau tidak mau harus diikuti kebutuhan pembaharuan hukum dan undang-undang yang mengaturnya.

Undang-undang Nomor 23 Tahun 1997 tentang Pengelolaan Lingkungan Hidup (UUPLH) memang telah bermanfaat bagi upaya pengelolaan lingkungan hidup di Indonesia, tetapi efektifitas implementasinya belum dapat mencapai tujuan yang diharapkan karena adanya persoalan pada masalah substansial, struktural maupun kultural. Kelemahan itu antara lain disebabkan belum adanya kewajiban pemerintah pusat maupun pemerintah daerah untuk melakukan perencanaan lingkungan sesuai sifat dan karakteristik pengelolaan. Belum adanya perencanaan lingkungan yang mapan antara lain telah menyebabkan banyak problem dalam penegakan hukumnya.

\footnotetext{
Edi Purwanto, 2007, Nasionalisme Lingkungan, Yogyakarta: Debut Wahana Sinergi, hlm. 7

Lembaga Kajian Ekologi dan Konservasi Lahan Basah, op.cit.
} 
Penegakan hukum adalah proses dilakukannya upaya tegaknya atau berfungsinya norma-norma hukum secara nyata sebagai pedoman perilaku dalam hubungan-hubungan hukum dalam kehidupan bermasyarakat dan bernegara. Ditinjau subyeknya, penegakan hukum itu dapat dilakukan oleh subyek yang luas dan dapat pula diartikan sebagai upaya penegakan hukum itu melibatkan semua subyek hukum dalam setiap hubungan hukum. Siapa saja yang menjalankan aturan normatif atau melakukan sesuatu atau tidak melakukan sesuatu dengan mendasarkan diri pada norma aturan hukum yang berlaku, berarti dia menjalankan atau menegakkan aturan hukum. Dalam arti sempit, dari segi subyeknya, penegakan hukum diartikan sebagai upaya aparatur penegak hukum tertentu untuk menjamin dan memastikan tegaknya hukum itu, apabila diperlukan, aparatur penegak hukum itu diperkenankan untuk menggunakan daya paksa.

Menurut Hawkins, istilah penegakan hukum (law enforcement) dapat dilihat dari dua sistem atau strategi yang disebut "compliance" dengan "conciliatory style" sebagai karakteristiknya, dan "sanctioning" dengan "penal style" sebagai ciri utamanya. Conciliatory style bersifat remedial, suatu metode "social repair and maintenance, assistance of people in trouble" yang berkaitan dengan "what is necessary to ameliorate a bad situation". Sedangkan penal control "prohibits with punishment", sifatnya adalah "accusatory", hasilnya "binary", yaitu: "all or nothing punishment or nothing".

Lebih lanjut notitie handhaving milleurecht, merumuskan penegakan hukum (rechtshandhaving) sebagai: ${ }^{8}$

Het door controle en het toepassen (of dreigen daarme) van administratiefrechtelijke, strafrechtelijke of privaatrechtelijke middelen bereiken dat de algemeen en individueel geldende

Keith Hawkins, 1984, Environment and Enforcement, Oxford: Clarendon Press, hlm. 3-4

8 Koesnadi Hardjasoemantri, 1994, Pengantar Penegakan Hukum Lingkungan Indonesia, Makalah Dalam Penataran Penegakan Hukum Lingkungan 9-14 Januari 1995, Eks Kerjasama Indonesia-Belanda, Surabaya: Fak. Hukum Unair, hlm. 1 rechtsregels en voorschriften worden nageleefd".

(Pengawasan dan penerapan (atau dengan ancaman) penggunaan instrumen administratif, kepidanaan atau keperdataan sehingga dicapai penaatan ketentuan hukum dan peraturan yang berlaku umum dan invidual).

Dalam pengertian pengawasan (controle), termasuk pengawasan pemerintah atas peraturan perundang-undangan. ${ }^{9}$ Dengan demikian penegakan hukum dapat dilakukan secara preventif maupun represif. Dalam penegakan hukum preventif berarti "pengawasan aktif dilakukan terhadap kepatuhan kepada peraturan tanpa kejadian langsung yang menyangkut peristiwa konkrit yang menimbulkan sangkaan bahwa peraturan hukum telah dilanggar". ${ }^{10}$ Sarana hukum administratif yang bersifat preventif bertujuan menegakkan peraturan perundang-undangan. ${ }^{11}$

Dalam penanganan masalah-masalah lingkungan, penegakan hukum preventif melalui sarana hukum administrasi menduduki posisi yang penting, karena fungsinya yang bertolak dari asas penanggulangan pada sumber (abatement at the source principle). ${ }^{12}$ Sehingga proses penegakan hukum melalui sarana hukum administrasi dianggap lebih memenuhi fungsi perlindungan "hak atas lingkungan hidup yang baik dan sehat" sebagai hak konstitusional. ${ }^{13}$ Pengutamaan penegakan hukum melalui sarana

9 ibid.

10 Siti Sundari Rangkuti, 1996,, Hukum Lingkungan dan Kebijaksanaan Lingkungan Nasional, Surabaya: Airlangga University Press, hlm. 190

11 Ibid., hlm. 192

12 Asas penanggulangan pada sumber (abatement at the source principle) terutama bertolak pada prioritas penanganan secara preventif. Lebih baik mencegah pencemaran atau menangani pada sumbernya daripada membersihkan kembali pencemaran yang telah terjadi. Dalam hukum lingkungan asas ini secara jelas dinyatakan dalam kewajiban perizinan terhadap aktivitas tertentu dengan persyaratannya. Izin dan persyaratannya bertujuan untuk mencegah pencemaran.

13 Hak atas lingkungan hidup yang baik dan sehat dalam UUD 1945 dirumuskan dalam Pasal 28H ayat (1) Bab XA tentang Hak Asasi Manusia, yang dirumuskan sebagai berikut: Setiap orang berhak hidup sejahtera lahir dan batin, bertempat tinggal, dan mendapatkan lingkungan hidup yang baik dan sehat serta berhak memperoleh pelayanan kesehatan 
hukum administrasi terutama berpijak pada beberapa alasan utama: ${ }^{14}$

1. Berfungsi sebagai sarana pengendalian, pencegahan dan penanggulangan perbuatan yang dilarang.

2. Instrumen yuridis hukum administrasi yang bersifat preventif dan berfungsi untuk mengakhiri atau menghentikan pelanggaran lingkungan.

3. Bersifat reparatoir (memulihkan pada keadaan semula).

4. Sanksi administrasi tidak perlu melalui proses pengadilan yang memakan waktu lama dan bertele-tele.

5. Sebagai sarana penecagahan dapat lebih efisien dari sudut pembiayaan dan waktu penyelesaian dibandingkan penegakan hukum pidana dan perdata.

6. Biaya penegakan hukum administrasi yang meliputi biaya pengawasan di lapangan dan pengujian laboratorium lebih murah dibandingkan biaya penumpulan bukti, investigasi lapangan, dan biaya saksi ahli untuk membuktikan aspek kausalitas (hubungan sebab akibat) dalam kasus pidana dan perdata.

Menurut Siti Sundari Rangkuti, dari segi bekerjanya hak atas lingkungan hidup yang baik dan sehat mengandung tuntutan yang bersifat hak asasi sosial, karena harus diimbangi dengan kewajiban pemerintah untuk menggariskan kebijaksanaan dan melakukan tindakan yang mendorong ditingkatkannya upaya pelestarian lingkungan. ${ }^{15}$ Pemenuhan hak tersebut ditindaklanjuti pemerintah dengan disahkannya Rancangan Undang-undang Perlindungan dan Pengelolaan Lingkungan Hidup (UU PPLH) menjadi undang-undang dalam Sidang Paripurna Dewan Perwakilan Rakyat pada hari Selasa tanggal 8 September 2009. Sebanyak sepuluh fraksi secara aklamasi menyetujui RUU PPLH menjadi UU PPLH 2009 sebagai pengganti UU Nomor 23 Tahun 1997 tentang Pengelolaan

\footnotetext{
14 Rosa Vivien Ratnawati, 2009, Penegakan Hukum Administrasi di Bidang Lingkungan Hidup, Jakarta: Kementerian Negara Lingkungan Hidup, hlm. 2-3

15 Siti Sundari Rangkuti, op. cit., hlm. 255
}

Lingkungan Hidup (UUPLH) dalam Sidang yang dipimpin Wakil Ketua DPR Muhaimin Iskandar.

Jika semula UUPLH 1997 hanya mencakup XI bab dan 52 pasal, maka UU PPLH sebagai penggantinya terdiri dari XVII Bab dan 127 Pasal. Ini berarti ketentuan pasalnya bertambah lebih dari 100 persen (55 pasal) dari undang-undang yang digantikannya. Naiknya ketentuan normatif dalam UU PPLH tersebut kiranya juga meningkatkan ekspektasi pemerhati lingkungan terhadap pemenuhan hak setiap orang atas lingkungan hidup yang baik dan sehat terhadap undang-undang baru ini. Benarkah demikian? Salah satu hal baru yang menarik untuk dikaji adalah penegakan hukum melalui sarana hukum administrasi sebagai sarana pencegahan pencemaran dan/atau perusakan lingkungan.

Masalah penegakan hukum merupakan masalah yang tidak sederhana, bukan saja karena kompleksitas sistem hukum itu sendiri, tetapi juga jalinan hubungan antara sistem hukum dengan sistem sosial, politik, ekonomi, dan budaya masyarakat. Sebagai suatu proses, penegakan hukum pada hakikatnya merupakan variabel yang mempunyai korelasi dan interdependensi dengan faktor-faktor lain. Ada beberapa faktor terkait yang mempengaruhi proses penegakan hukum sebagaimana diungkapkan oleh Lawrence M Friedman, yaitu komponen substansi, struktur dan kultural. $^{16}$ Komponen tersebut termasuk ruang lingkup bekerjanya hukum sebagai suatu sistem. Kesemua faktor tersebut akan sangat menentukan proses penegakan hukum dalam masyarakat dan tidak dapat dinafikan satu dengan lainnya. Kegagalan pada salah satu komponen akan berimbas pada faktor lainnya.

Pembahasan tulisan ini berusaha mengkaji penegakan hukum lingkungan melalui sarana hukum administrasi. Terutama melalui sarana hukum pengawasan dan izin terhadap pengaturan dalam UU PPLH yang baru. Pembahasan dititikberatkan pada aspek struktur

16 Lawrence M Friedman, Legal Rules and the Process of Social Change", Stanford Law Review, 1967, disunting ulang dari Satjipto Rahardjo, Penegakan Hukum, Sutu Tinjauan Sosiologis, Yogyakarta: Genta Publishing, 2009, hlm. 8. 
(kelembagaannya) dan aspek substansi (peraturan perundang-undangannya).

\section{B. Pembahasan}

\section{Penegakan Hukum Preventif Melalui Peng- awasan}

Hukum lingkungan sebagai genus merupakan cabang ilmu tersendiri, namun bagian terbesar substansinya merupakan ranting hukum administrasi. Hal ini mengingat pengelolaan lingkungan dilakukan terutama oleh pemerintah sehingga hukum lingkungan sebagian besar terdiri atas hukum pemerintahan (bestuurrecht). ${ }^{17}$ Bestuurrecht disebut juga administratief recht, atau hukum administrasi. ${ }^{18}$ Hukum Administrasi berisi peraturanperaturan yang antara lain berhubungan dengan perlindungan hukum bagi rakyat. Maka peraturan perundang-undangan lingkungan yang dilahirkan pemerintah lazimnya berupa sarana kebijaksanaan (beleids instrumentarium) yang bersifat hukum administrasi. Seperti dikatakan Drupsteen dan Kleijs-Wijnnobel bahwa: ${ }^{19}$

Bagian terbesar dari hukum lingkungan terdiri dari ketentuan-ketentuan hu-kum administratif. Ketentuan-ketentu-an tersebut, pada satu pihak, merupa-kan norma-norma materiil yang mengikat warga. Di lain pihak ketentu-an tersebut juga mengatur batas ke-wenangan dan organisasi penguasa dalam hal pelaksanaan norma-norma materiil.

Dominannya ketentuan hukum administrasi dalam hukum lingkungan berkaitan langsung dengan sifat dan ruang lingkup problematik lingkungan. Problematik lingkungan tersebut adalah sedemikian rupa hingga tidak mungkin

17 Drupsteen, Th.G., 1993, Nederlands Milleurecht in Korts Bestek, 2e druk, W.E.J, Tjeenk Willink, Zwolle, 1978. Disunting ulang dari Koesnadi Hardjasoemantri, Hukum Tata Lingkungan, Edisi Kelima, Yogyakarta: Gadjah Mada University Press, hlm. 15-16

18 Philipus M Hadjon, dkk., 1993, Pengantar Hukum Administrasi Indonesia (Introductiona to the Indonesian Administrative Law), Yogyakarta: Gadjah Mada University Press, hlm. 3-4

19 Drupsteen, Th.G en Kleijs-Wijnnobel, C.J., 1994, Handhaving van Milleurecht door middel van Civiel, Administratif en Strafrecht, disunting ulang dari Tristam P Moeliono, Kekhawatiran Masa Kini, Pemikiran Mengenai Hukum Pidana Lingkungan Dalam Teori dan Praktek, Bandung: Citra Aditya Bakti, hlm. 14 dapat diselesaikan secara efektif melulu melalui hak-hak dan kewenangan yang didasarkan pada hukum privat. ${ }^{20}$ Karena itu, hukum dari penguasa yaitu hukum administrasi sangat berperan dalam penanganan masalah-masalah lingkungan. ${ }^{21}$

Dalam undang-undang lingkungan hidup yang lama (UUPLH) kewenangan pengawasan secara atribusi ${ }^{22}$ diberikan kepada Menteri berdasarkan Pasal 22 ayat (1). Ketentuan ini bertujuan untuk memberikan wewenang yang lebih tegas kepada Menteri Negara Lingkungan Hidup (MNLH) untuk melakukan pengawasan. Namun demikian, menteri sektoral (sebagai pejabat yang mengeluarkan izin) dengan sendirinya juga berwenang melakukan pengawasan. Bedanya, menteri sektoral yang bersangkutan berwenang melakukan pengawasan umum dan khusus atas semua ketentuan yang berkaitan dengan izin. Sedangkan MNLH hanya melakukan pengawasan umum berkaitan syarat-syarat lingkungan yang ditetapkan dalam peraturan perundang-undangan. Persoalan teknis yang muncul, meskipun MNLH mempunyai wewenang untuk melakukan pengawasan umum namun tetap tidak mempunyai kewenangan untuk menjatuhkan sanksi administratif jika hasil pengawasan menunjukkan adanya pelanggaran. Karena MNLH tidak mempunyai wewenang untuk menerbitkan izin. Sehingga tidak mempunyai wewenang administratif struktural dalam pengelolaan lingkungan hidup. Dengan kondisi ini maka MNLH harus tetap melakukan koordinasi dengan menteri sektoral, yang membuat proses birokrasi penegakan hukum menjadi lebih panjang.

Persoalan teknis tersebut kiranya hendak diperbaiki oleh UU PPLH yang baru, yaitu

20 Pada beberapa kasus lingkungan dengan korban dalam jumlah ratusan bahkan ribuan, meskipun prosedur hukum privat telah menyediakan gugatan kelompok (class action) jika korban diberikan gantirugi, kerugian akan diberikan kepada korban secara sama sesuai dengan perhitungan rata-rata kelompok kelasnya. Faktanya kerugian korban sangat bervariasi sehingga penyelesaian ini tetap dipandang tidak efektif dari sisi keadilan.

21 Tristam P Moeliono., loc. cit.

22 Dalam teori wewenang terdapat tiga jenis sumber wewenang, yaitu: wewenang atribusi, delegasi, dan mandat. Wewenang atribusi adalah wewenang asli yang berikan kepada pejabat secaralangsung dari peraturan perundang-undangan. 
dengan memberikan kewenangan menteri untuk menerbitkan izin lingkungan.

Pasal 36 UU PPLH:

(1) Setiap usaha dan/atau kegiatan yang wajib memiliki amdal atau UKL-UPL wajib memiliki izin lingkungan.

(2) Izin lingkungan sebagaimana dimaksud pada ayat (1) diterbitkan berdasarkan keputusan kelayakan lingkungan hidup sebagaimana dimaksud dalam Pasal 31 atau rekomendasi UKLUPL.

(3) Izin lingkungan sebagaimana dimaksud pada ayat (1) wajib mencantumkan persyaratan yang dimuat dalam keputusan kelayakan lingkungan hidup atau rekomendasi UKL-UPL.

(4) Izin lingkungan diterbitkan oleh Menteri, gubernur, atau bupati/ walikota sesuai dengan kewe-nangannya.

Lebih lanjut Pasal 1 angka 35 UU PPLH merumuskan izin lingkungan sebagai:

Izin lingkungan adalah izin yang diberikan kepada setiap orang yang melakukan usaha dan/atau kegiatan yang wajib amdal atau UKL-UPL dalam rangka perlindungan dan pengelolaan lingkungan hidup sebagai prasyarat untuk memperoleh izin usaha dan/ atau kegiatan.

Dengan demikian UUPLH telah menciptakan satu jenis izin baru yang selama ini dihindari pemerintah, ${ }^{23}$ yakni: izin lingkungan. Izin ini ternyata tidak diwajibkan kepada semua kegiatan/usaha yang berdampak bagi lingkungan. Tetapi hanya diwajibkan bagi kegiatan/ usaha yang wajib dilakukan Analisis Mengenai Dampak Lingkungan (Amdal) atau kegiatan yang wajib dilakukan kajian Rencana Pengelolaan

23 Sejak Undang-undang Lingkungan Hidup yang pertama (UULH 1982) pemerintah mencoba untuk tidak menciptakan jenis izin baru dalam penanganan masalah lingkungan. Hal ini karena Indonesia telah dikenal sebagai "negara dengan hutan perizinan" (vergunning staat) karena banyak jenis izin. Sehingga dalam pengelolaan lingkungan tidak dikehendaki jenis izin baru yang dapat menambah birokrasi. Syarat-syarat lingkungan cukup diintegarsikan dalam izin-izin yang sudah ada. Meskipun dalam pelaksanaannya pemerintah tidak dapat mempertahankan kebijakan ini, yakni dengan munculnya izin pembuangan limbah cair berdasarkan PP no. 20 tahun 1990 tentang pengendalian limbah cair, atau izin pembuangan limbah ke media lingkungan berdasarkan Pasal 20 ayat (1) UUPLH 1997
Lingkungan atau Rencana Pemantauan Lingkungan (RKL-RPL). ${ }^{24}$

Menurut Pasal 36 ayat (4) izin lingkungan diterbitkan oleh Menteri, gubernur, atau bupati/walikota sesuai dengan kewe-nangannya. Dengan ketentuan ini maka menteri (LH), gubernur, dan bupati/walikota harus menetapkan jenis kegiatan/usaha yang wajib Amdal dan wajib RKL-RPL. Pengalaman terdahulu menunjukkan bahwa pemerintah pusat (MNLH) umumnya hanya menetapkan jenis kegiatan/usaha yang wajib dilengkapi Amdal saja, tanpa menetapkan jenis kegiatan atau usaha yang wajib dilengkapi RKL-RPL.25 Penetapan kegiatan yang wajib RKL-RPL hanya didasarkan pada teori sisa, yakni kegiatan yang tidak wajib Amdal harus dilengkapi RKL-RPL. Dengan ketentuan ini maka pemerintah daerah (gubernur dan walikota) harus berinisiatif untuk menetapkan kegiatan yang wajib dilengkapi RKL-RPL. Prakteknya tidak semua pemerintah daerah menetapkan hal itu. Sehingga semua kegitan/usaha yang tidak wajib Amdal harus dilengkapi dengan RKL-RPL. Atau, jika pemerintah daerah menetapkannya hal itu dilakukan dengan prinsip "pukat harimau" dengan menetapkan sebanyak kegiatan/usaha yang wajib dilengkapi RKL-RPL.

Tidak dapat dipungkiri jika hal ini dilakukan oleh banyak pemerintah daerah untuk menambah prosedur administrasi terkait pungutan yang mungkin dapat dimanfaatkan. "Kreatifitas" itu tentu akan memperpanjang birokrasi dan menambah rente ekonomi yang berakibat pada biaya tinggi dalam investasi. Dengan kondisi ini kiranya harus menjadi pelajaran bagi pemerintah pusat terkait kebijakan izin lingkungan yang ditetapkan dalam UU PPLH 2009. Pemerintah kiranya tidak hanya sekedar menetapkan kegiatan/usaha yang wajib amdal saja, tetapi sekaligus menetapkan jenis kegiatan yang wajib dilengkapi RKL-RPL. Setidaknya,

24 Ketentuan ini ditegaskan lagi dalam Pasal 36 ayat (1) yang menetapkan: Setiap usaha dan/atau kegiatan yang wajib memiliki amdal atau UKL-UPL wajib memiliki izin lingkungan

25 Contohnya adalah KEPMEN LH Nomor 39 Tahun 1996 tentang Jenis Usaha atau Kegiatan yang wajib dilengkapi dengan Analisis Mengenai Dampak Lingkungan 
pemerintah dapat menetapkan kriterium umum jenis kegiatan/usaha yang wajib RKL-RPL, yang dapat menjadi pedoman bagi pemerintah daerah dalam menetapkan jenis kegiatan/ usaha yang wajib RKL/RPL. Hal tersebut dapat mereduksi disparitas penegakan hukum antar pemerintah daerah terkait kegiatan/usaha yang wajib dileng-kapi RKL-RPL.

Terkait pengawasan terhadap kepatuhan peraturan perundang-undangan dan ketentuan yang ditetapkan dalam dokumen amdal dan RKL-RPL ditetapkan dalam Pasal 71 dan Pasal 72 UU PPLH sebagai berikut:

\section{Pasal 71}

(1) Menteri, gubernur, atau bupati/walikota sesuai dengan kewenang-annya wajib melakukan pengawasan terhadap ketaatan penanggung jawab usaha dan/atau kegiatan atas ketentuan yang ditetapkan dalam peraturan perundang-undangan di bidang perlindungan dan pengelolaan lingkungan hidup.

(2) Menteri, gubernur, atau bupati/wali kota dapat mendelegasikan kewenangannya dalam melakukan pengawasan kepada pejabat/instansi teknis yang bertanggung jawab di bidang perlindungan dan pengelolaan lingkungan hidup.

(3) Dalam melaksanakan pengawasan, Menteri, gubernur, atau bupati/ walikota menetapkan pejabat pengawas lingkungan hidup yang merupakan pejabat fungsional.

\section{Pasal 72 UU PPLH:}

Menteri, gubernur, atau bupati/walikota sesuai dengan kewenangannya wajib melakukan pengawasan ketaatan penanggung jawab usaha dan/atau kegiatan terhadap izin lingkungan.

Dengan demikian, menteri, gubernur, dan bupati/walikota sebagai penerbit izin lingkungan mempunyai kewajiban untuk melakukan pengawasan atas kepatuhan pemegang izin terhadap syarat-syarat lingkungan baik yang ditetapkan dalam peraturan perundang-undangan, sebagai syarat-syarat umum, maupun yang ditentukan dalam izin lingkungan, sebagai syarat khusus. Kewenangan ini selanjutnya akan dilimpahkan kepada pejabat pengawas lingkungan hidup, baik di daerah maupun pusat.

Penegakan hukum lingkungan melalui kewenangan pengawasan tidak dapat berjalan dengan baik jika substansi tidak ada peraturan perundang-undangan yang mendukung proses penegakan hukum itu. Oleh karena itu, untuk menjamin pelaksanaan penegakan hukum lingkungan melalui pengawasan terdapat beberapa elemen kunci yang harus diatur dalam peraturan perundang-undangan dalam kaitan dengan pengawasan adalah: ${ }^{26}$

a. Jumlah pengawas (proporsional dengan jumlah populasi, cakupan geografis dan obyek yang diawasi;

b. Kriteria untuk menentukan target pengawasan;

c. Frekuensi pengawasan;

d. Standarisasi laporan pengawasan;

e. Prosedur tindak lanjut pengwasan.

Pada masa lalu jumlah Pejabat Pengawas Lingkungan Hidup (PPLH) yang bertugas mengawasi amdal tidak sebanding dengan jumlah pabrik yang harus diawasi. Tugas pengawasan amdal adalah peran paling strategis MNLH untuk mencegah kerusakan lingkungan dan menerima pengaduan dari masyarakat. Oleh karena itu, jumlah PPLH agar proporsional dengan jumlah perusahaan dan pabrik yang harus diawasi. ${ }^{27}$

\section{Ijin Lingkungan dan Penegakan Hukum}

Hal kedua yang perlu dikaji terkait izin lingkungan adalah adalah rumusan Pasal 1 angka 35 yang menetapkan bahwa izin lingkungan merupakan prasyarat untuk memperoleh izin usaha dan/atau kegiatan. ${ }^{28}$ Ketentuan ini menegaskan bahwa izin lingkungan merupakan bagian dari mata rantai perizinan usaha/kegiatan. Berpijak pada jenis perizinan dalam peraturan perundang-undangan yang harus dipenuhi penanggungjawab usaha/kegiatan, setidaknya mencakup:

26 Rosa Vivien Ratnawati, op. cit, hlm. 4

27 Tempo Interaktif, ICEL minta KLH tambah jumlah pengawas lingkungan, Jumat 16 Desember 2005

28 Ketentuan ini juga ditegaskan dalam Pasal 40 ayat (1) UU PPLH 2009, bahwa: Izin lingkungan merupakan persyaratan untuk memperoleh izin usaha dan/atau kegiatan 
254 Jurnal Dinamika Hukum

Vol. 9 No. 3 September 2009

a. Izin lokasi;

b. izin Mendirikan Bangunan (IMB);

c. izin berdasarkan ordonansi gangguan (izin $\mathrm{HO}$ );

d. izin lingkungan;

e. izin usaha/kegiatan (seperti: izin usaha industri dan lain-lain). ${ }^{29}$

Selanjutnya Pasal 40 ayat (2) UUPLH 2009 menetapkan bahwa: Dalam hal izin lingkungan dicabut, izin usaha dan/atau kegiatan dibatalkan. Ketentuan ini berangkat dari timbulnya berbagai persoalan di masa lalu terkait dengan keterpaduan izin sebagai mata rantai yang saling berhubungan. Selama ini berbagai jenis izin yang ada belum menunjukkan adanya sifat keterpadu-an tersebut. Dalam banyak kasus, pada masa lalu jika salah satu jenis izin (misalnya izin $\mathrm{HO}$ ) dicabut karena adanya pelanggaran terhadap syarat-syarat yang ditentukan dalam izin, pemegang izin akan tetap berkeras untuk menjalankan usaha/ kegiatannya. Karena yang dicabut hanya izin HOnya saja, sedangkan izin usahanya tidak. Maka pemegang izin tetap berhak untuk menjalankan kegiatan/usahanya. Ketentuan dalam Pasal 40 ayat (2) kiranya ditujukan untuk mengatasi hal tersebut.

Namun demikian, Pasal 40 ayat (2) menetapkan bahwa jika izin lingkungan dicabut, maka izin usaha atau kegiatan harus dilakukan pembatalan. Ketentuan ini mempunyai dua konsekuensi hukum penting yang perlu dikaji akibat teknisnya. Pertama, bahwa pencabutan izin lingkungan tidak dengan sendirinya mengakibatkan penanggungjawab usaha/kegiatan harus menghenti-kan kegiatan/usahanya. Agar kegiatan/usaha tersebut dapat dihentikan, harus ditindak lanjuti lebih dulu dengan pembatalan izin usaha/kegiatan oleh instansi penerbit izin usaha/kegiatan.

Prakteknya pembatalan izin usaha/kegiatan sangat selektif dilakukan oleh pemerintah. Terutama terkait dengan akibat ekonomis menyangkut tenaga kerja dan pasokan produk industri yang dihasilkan. Akibat ini akan sangat

29 Dalam penjelasan pasal ini pengertian izin usaha bahkan diperluas yang mencakup dalam pengertian lain seperti izin oprasi atai izin konstruksi. diperhitungkan oleh instansi penerbit izin usaha/kegiatan, yang cenderung akan mempertahankan kegiatan/ usaha tersebut. Jika hal ini terjadi maka terdapat peluang terjadinya konflik kepentingan antar instansi pemerintah, dalam hal ini MNLH dengan instansi sektoral penerbit izin. Dengan demikian, meskipun ketentuan dalam Pasal 40 ayat (2) memberi wewenang atribusi kepada MNLH untuk melakukan pencabutan izin lingkungan, tetap dibutuhkan adanya koordinasi antara MNLH dengan instansi sektoral yang terkait. Ini mutlak dilakukan untuk menghindari kemungkinan terjadinya konflik tersebut.

Kedua, adalah menyangkut terminologi hukum yang dirumuskan dalam Pasal 40 ayat (2) di atas. Pasal ini menyatakan: "dalam hal izin lingkungan dicabut, izin usaha dan/atau kegiatan dibatalkan". Pembedaan terminologi hukum "dicabut" dan "dibatalkan" dalam satu ketentuan norma tentu mengandung konsekuensi bahwa istilah tersebut ditujukan pada makna yang berbeda. Dalam UU PPLH 2009 ternyata hanya terdapat dua kata yang menggunakan istilah dicabut, yakni Pasal 40 ayat (2) dan Pasal 125. Dalam pasal 125 istilah ini digunakan dalam ketentuan penutup tentang pencabut-an dan pernyataan tidak berlakunya lagi UUPLH 1997 setelah berlakunya UU PPLH 2009 ini. Ini berbeda dengan istilah "dibatalkan” yang digunakan dalam tiga pasal secara konsisten, antara lain Pasal 37. Pasal 37 ayat (2) UU PPLH menentukan:

Izin lingkungan sebagaimana dimaksud dalam Pasal 36 ayat (4) dapat dibatalkan apabila:

a. persyaratan yang diajukan dalam permohonan izin mengandung cacat hukum, kekeliruan, penyalahgunaan, serta ketidakbenaran dan/atau pemalsuan data, dokumen, dan/atau informasi;

b. penerbitannya tanpa memenuhi syarat sebagaimana tercantum dalam keputusan komisi tentang kelayakan lingkungan hidup atau rekomendasi UKL-UPL; atau

c. kewajiban yang ditetapkan dalam dokumen amdal atau UKL-UPL tidak dilaksanakan oleh penanggung jawab usaha dan/atau kegiatan. 
Dengan demikian pembatalan izin lingkungan dapat dilakukan baik karena cacat prosedural/substansial yang terjadi sebelum izin diterbitkan (butir a dan b), atau karena ada pelanggaran terhadap syarat-syarat dalam izin (butir c). Berpijak pada ketentuan ini, maka istilah "dicabut" dalam Pasal 40 ayat (2) sebenarnya merujuk pada pembatalan karena pelanggaran syarat-syarat yang ditentukan dalam izin atau peraturan perundang-undangan. Jika demikian, apa alasannya pembentuk undang-undang meng-gunakan istilah yang berbeda dengan terminologi yang ditentukan dalam Pasal 37 ayat (2) butir c? Pada tingkat teknis, terutama jika pencabutan itu menjadi sengketa admiistrasi, hal tersebut tentu dapat me-nimbulkan problem hukum, dimana para pemegang izin lingkungan dapat menolak pencabutan izin berdasarkan Pasal 42 ayat (2) di atas. Karena berpijak pada pasal 37 ayat (2) pelanggaran atas syarat-syarat lingkungan hanya dapat dibatalkan, bukan dicabut, meskipun akibat hukumnya sama.

Inkonsistensi rumusan tersebut dapat menimbulkan persoalan dalam penegakan hukumnya., Secara konseptual menurut Satjpto Rahardjo, penegakan hukum sudah dimulai pada saat peraturan hukumnya dibuat atau diciptakan. Penegakan hukum adalah suatu proses untuk mewujudkan keinginan hukum menjadi kenyataan. Keinginan hukum adalah pikiran-pikiran badan pembuat undang-undang yang dirumuskan dalam peraturan hukum. ${ }^{30}$ Maka peranan peraturan hukum cukup besar dalam hubungannya dengan pelaksanaan peraturan yang dilakukan oleh para penegak hukum. Lebih lanjut ditegaskan pula: ${ }^{31}$

Dapat dikatakan bahwa keberhasilan atau kegagalan para penegak hukum dalam melaksanakan tugasnya sebetulnya sudah dimulai sejak peraturan yang harus dijalankan tersebut dibuat. Misalnya, badan legislatif membuat peraturan yang sulit dilaksanakan dalam masya-

\footnotetext{
30 Satjipto Rahardjo, 2009, Penegakan Hukum Suatu Tinjauan Sosiologis, Yogyakarta: Genta Publishing, hlm. 24

31 Ibid., hlm. 25
}

rakat, maka sejak saat itu sebetulnya badan tersebut telah menjadi arsitek bagai kegagalan para penegak hukum dalam menerapkan peraturan tersebut.

Jelas perumusan Pasal 40 ayat (2) UU PPLH 2009 bertentangan dengan asas pembentukan peraturan perundang-undangan yang baik, khususnya asas kejelasan rumusan yang tertuang dalam Pasal 5 butir $f$ Undang-undang Nomor 10 Tahun 2004 tentang Pembentukan Peraturan Perundang-undangan. Penjelasan pasal ini menyatakan bahwa: "Yang dimaksud dengan asas "kejelasan rumusan" adalah bahwa setiap Peraturan Perundang-undangan harus memenuhi per-syaratan teknis penyusunan Peraturan Perundang-undangan, sistematika dan pilih-an kata atau terminologi, serta bahasa hukumnya jelas dan mudah dimengerti, sehingga tidak menimbulkan berbagai macam interpretasi dalam pelaksanaannya".

Bagi penegak hukum, menegakkan hukum berarti memberikan kepastian dan keadilan dalam suatu peristiwa dengan tujuan menerapkan hukum yang ada dalam peraturan (in abstracto) dengan menerapkan pada kasus nyata (in concreto). Dalam posisi ini peraturan hukum mempunyai kedudukan yang sangat penting. Ditegaskan oleh Soerjono Soekanto bahwa gangguan terhadap penegakan hukum yang berasal dari undang-undang mungkin disebabkan kare-na: ${ }^{32}$

a. Tidak diikutinya asas-asas berlakunya undang-undang;

b. Belum adanya peraturan pelaksanaan yang sangat dibutuhkan untuk menerapkan undang-undang;

c. Ketidakjelasan arti kata di dalam undangundang yang mengakibatkan kesimpangsiuran di dalam penafsiran serta penerapannya.

Dalam proses penegakan hukum, faktor hukum (peraturan perundang-undangan) juga berkaitan dengan faktor penegak hukumnya dan secara yuridis memiliki keterkaitan dan bersifat saling mempengaruhi. Peraturan yang

\footnotetext{
32 Soerjono Soekanto, 1983, Faktor-Faktor Yang Mempengaruhi Penegakan Hukum, Jakarta: CV. Rajawali, hlm. 17-18
} 
baik akan sangat ber-pengaruh pada proses dan hasil penegakan hukum. Demikian sebaliknya, kemampuan penegak hukum berpengaruh terhadap penerapan hukum secara tepat. Dengan demikian, dalam penegakan hukum terkait dengan izin lingkungan tersebut, kreatifitas penegak hukum terhadap kompleksitas substansi UU PPLH 2009 sangat menentukan keberhasilan proses penegakan hukum lingkungan. Dalam hal ini, penegak hukum tetap dapat berpijak pada Pasal 37 ayat (2) UU PPLH dengan menggunakan istilah pembatalan dalam keputusannya. Sedangkan pembatalan izin usaha/kegiatan oleh instansi sektoral, setelah rencana pembatalan izin lingkungan dikoordinasikan, pembatalannya tidak mendasarkan pada Pasal 40 ayat (2). Tetapi menggunakan landasan hukum yang tercantum dalam izin usaha/kegiatan itu sendiri atau peraturan perundang-undangan sektoral yang menjadi dasar penerbitan izin usaha/ kegiatan.

\section{Penutup}

1. Secara struktural kelembagaan, penegakan hukum lingkungan melalui sarana pengawasan lingkungan UU PPLH tidak mengamanatkan pembentukan lembaga baru yang secara khusus menangani, seperti halnya Badan Pengnedalian Dampak Lingkungan (Bappedal) pada masa lalu. Konstruksi ini mengakibatkan pengawasan oleh Menteri Negara Lingkungan Hidup (MNLH) harus dikoordinasikan dengan departemen/instansi sektoral. Oleh karena itu, dalam hal terjadi pelanggaran administratif atas syarat-syarat yang ditentukan dalam Amdal atau RKL-RPL yang berakibat pada penjatuhan sanksi pembatalan izin, MNLH harus mengkoordinasikan seawal mungkin untuk menghindari konflik antar pejabat administrasi. Sedangkan secara substansial, pengawasan lingkungan hidup perlu dukungan rinci peraturan perundang-undangan yang menyangkut proporsi pengawas dengan wilayah yang diawasi, standar laporan, maupun frekuensi pengawasan.

2. Penegakan hukum lingkungan melalui sarana pengawasan atas perizinan lingkungan dapat menemui kendala yang cukup berarti terkait inkonsistensi terminologi yang digunakan. Karena itu, perlu kreatifitas penegak hukum untuk menghindari problem hukum yang muncul apabila penegakan hukum berkembang menjadi sengketa di pengadilan administrasi.

\section{Daftar Pustaka}

Hadjon, Philipus M, dkk. 1993. Pengantar Hukum Administrasi Indonesia (Introduction to the Indonesian Administrative Law). Yogyakarta: Gadjah Mada University Press;

Hardjasoemantri, Koesnadi. 1993. Hukum Tata Lingkungan. Edisi Kelima, Yogyakarta: Gadjah Mada University Press;

-.---.-. 1994. Pengantar Penegakan Hukum Lingkungan Indonesia. Makalah Dalam Penataran Penegakan Hukum Lingkungan 914 Januari 1995, Eks Kerjasama Indonesia-Belanda, Surabaya: Fak. Hukum Unair;

Hawkins, Keith. 1984. Environment and Enforcement. Oxford : Clarendon Press

Kementerian Lingkungan Hidup. 2004. Environmental Parliament Watch (EPW) Menuju Perwujudan Peran Masyarakat. Jakarta: Deputi Bidang Pengembangan Peran Masyarakat;

-.----.-. 2005. Laporan Menteri Lingkungan Hidup Tahun 2005. Jakarta;

Lembaga Kajian Ekologi dan Konservasi Lahan Basah, Melaksanaan Pembangunan Berkelanjutan Dengan Menegakkan Hukum Lingkungan Bagi Pencemar, 5 Juni 2002;

Moeliono, Tristam P. 1994. Kekhawatiran Masa Kini, Pemikiran Mengenai Hukum Pidana Lingkungan Dalam Teori dan Praktek. Bandung: Citra Aditya Bakti;

Purwanto, Edi. 2007. Nasionalisme Lingkungan. Yogyakarta: Debut Wahana Sinergi;

Ratnawati, Rosa Vivien. 2008. Penegakan Hukum Administrasi di Bidang Lingkungan Hidup, Jakarta: Kementerian Negara Lingkungan Hidup;

Rahardjo, Satjipto. 2009. Penegakan Hukum, Suatu Tinjauan Sosiologis. Yogyakarta: Genta Publishing; 
Rangkuti, Siti Sundari. 1996. Hukum Lingkungan dan Kebijaksanaan Lingkungan Nasional. Surabaya: Airlangga University Press;

Soekanto, Soerjono. 1983. Faktor-Faktor Yang Mempengaruhi Penegakan Hukum. Jakarta: CV. Rajawali;
Tempo Interaktif, ICEL minta KLH tambah jumlah pengawas lingkungan, Jumat 16 Desember 2005. 